\title{
DRYING BEHAVIORS OF WATER HYACINTH BY MULTI-TRAY SOLAR DRYER
}

\author{
SHOUGHY M. I., A. F. ABDRABOH and A. B. EL-NAGAR
}

Agric. Eng. Res. Inst. (AEnRI) , ARC Dokki, Giza, Egypt.

(Manuscript received 11 January 2014)

\begin{abstract}
This study evaluated the drying behaviors of complete and compressed water hyacinth $(\mathrm{WH})$ by Multi-tray solar dryer under Kafrelsheikh governorate weather conditions during summer season, 2013. A multi-tray solar dryer, which manufactured and tested in Rice Mechanization Center, Agric. Eng. Res. Inst. for drying fish successfully, was used. Heated air in solar air collector was forced through the drying chamber by a radial fan. In order to explain the drying behavior of $\mathrm{WHs}$, four different mathematical models were compared and the moisture ratios obtained experimentally and the drying coefficients of models tested were determined by nonlinear regression analysis. The experimental data were fitted into Newton, Page's, Henderson and Pabis and Logarithmic drying models. During the drying period, ambient and drying air temperatures, relative humidity and the losses of mass were measured continuously. The average ambient temperature, air temperature and relative humidity of drying chamber and solar radiation incident were of about $30.3^{\circ} \mathrm{C}, 51.5^{\circ} \mathrm{C}, 36 \%, 540 \mathrm{~W} / \mathrm{m}^{2}$, respectively. Drying took place entirely in the falling rate period. The drying rate decreased with increasing drying time and decreasing moisture content. The compressed WH had the shortest drying time than the complete WH samples. The solar drier increased drying rate by about 1.5-2 times, while the drying time decreased by $50 \%$ as compared to sun drying samples. The logarithmic model could adequately describe the drying behaviors of complete and compressed WH by multi-tray solar drier and has shown a better fit to the experimental drying data with highest coefficient of determination (0.997) and lowest $\mathrm{X}^{2}$, MBE and RMSE. Effective moisture diffusivity values of complete and compressed WH of about $6.65 \times 10^{-8} \mathrm{~m}^{2} / \mathrm{s}$ and $8.16 \times 10^{-8} \mathrm{~m}^{2} / \mathrm{s}$, respectively. The results obtained are comparable to some of the reported works.
\end{abstract}

\section{INTRODUCTION}

In order to select an appropriate dryer and the drying parameters such as drying time and temperature, it is important to understand the drying behavior of the material to be dried because of the drying behavior of crops is usually different. The Water hyacinth (Eichhornia crassipes $\mathrm{L}$ ) is a free-floating plant growing in fresh-water. It has attracted significant attention as the world's worst invasive aquatic plant due to its extremely rapid proliferation and congests growth, presenting serious challenges in navigation, irrigation, and power generation. Attempts to control the weed have 
proved to be costly with minimum results. Consequently, research activity on utilization of the plant has been registered over the last few decades. Utilization of $\mathrm{WH}$ is an important way of managing the weed problem and contributing to environmental management as well as creating employment and generating income for those who are most affected by it. Many studies have been conducted to evaluate utilization of WH for such uses as animal feed, as a fuel, handicrafts, furniture, biogas, compost, rope, pollution abatement and paper pulp with limited success (Casas et al., 2012). The $\mathrm{WH}$ is also used to treat waste water from dairies, tanneries, sugar factories, pulp and paper industries, palm oil mills, distilleries, etc. The major problem in these applications is the high cost of transportation of freshly removing $\mathrm{WH}$ from water bodies to the factories. Capacities of mechanical management systems for aquatic plants are usually limited by the volume of the plant material that must be handled, transported and stored. As fresh $\mathrm{WH}$ has around $92 \%$, w.b., moisture content with the bulk density of approximately $96 \mathrm{~kg} / \mathrm{m}^{3}$, it necessitates handling a plant volume of $130 \mathrm{~m}^{3}$ and disposing of 9.2tonnes of water for every tone of dry matter removed from the site (Innocent et al., 2008). The high moisture content increases microbial activity hence deteriorating the quality of a material. In order to use the WH as a complete material for handicraft making, hence increasing the production of fiber products by crafts people and cottage industries, its water content must be lowered through a drying process. Compacting or squeezing also is a type of size reduction that deals with the application of force to a unit being reduced in excess of WH moisture content. Drying also brings about product conservation as well as substantial reduction in weight and volume whereby a decrease in packaging, storage and transportation costs can be achieved. Currently, the conventional dryers are not economic energy due to high cost. The energy utilization was a multifaceted involving a function of the material properties (such as size, shape, moisture bonding, and initial and final moisture content), dryer design (configuration, type and mode of heating), and drying process variables (temperature, air velocity and humidity). Sundrying method lacks control in the quality of the product and highly dependent on weather, making it very inefficient and unreliable. Properly designed solar drying systems must take into account drying requirements of specific crops. Simulation models are needed in the design, construction and operation of drying systems. However only thin layer drying models are widely used for the designing of the dryers. In many rural locations in most developing countries, grid-connected electricity and supplies of other non-renewable sources of energy are unavailable, unreliable or, too expensive. In such conditions, solar dryers appear increasingly to be attractive as commercial propositions (Xingxing et al., 2012). Because the performance of the solar 
tunnel dryer will differ place to place depending upon the availability of solar radiation of a particular place. Ajala et al., (2012) worked on statistical modeling and simulation of solar tunnel drying process. This study was undertaken to investigate drying kinetics of complete and compressed WH in a new manufactured solar tunnel dryer in Kafrelsheikh, and to fit the experimental data obtained to mathematical models available in literature to describe thin-layer drying behaviors of WH which were not reported earlier.

\section{MATERIALS AND METHODS}

\section{Sample preparation and experimental side:}

Water hyacinth samples were collected from canals near the RMC in Kafrelsheikh. The roots of the plant were cut off. Only the stem and leaves of the plant was acquired. A part from WH samples were washed and cut into halves by a knife into $10 \mathrm{~cm}$ long and the other was dewatering by using the developed compressing and chopping machine. The initial moisture content of WH samples was determined using the hot air oven at $130^{\circ} \mathrm{C}$ for $24 \mathrm{~h}, A O A C$ (2005). The experiments were carried out in the experimental site of RMC at Meet El-Deeba, Kafrelsheikh Governorate weather conditions, which lies at latitude $31.07^{\circ} \mathrm{N}$ and longitude $30,57^{\circ} \mathrm{E}$ during summer, 12-13, June, 2013.

\section{Dewatering}

The prepared samples underwent dewatering or compressed and chopped by using the Star Forage chopper machine model (SC-18C), which developed and tested in the experimental site of RMC for volume and biomass reduction of fresh $\mathrm{WH}$. The machine was operated at optimum condition. Before passing through the machine rollers the mass of the prepared samples was determined. After passing, the samples were massed again and placed in the drying trays. The following equation computed the percentage of water removed, Casas et al., (2012):

Water removed, $\%=\frac{\mathrm{m}_{\mathrm{i}}-\mathrm{m}_{\mathrm{f}}}{\mathrm{m}_{\mathrm{i}}} \times 100 \%$

Where: $m_{i}$ is the mass of the sample before passing through the machine and $m_{f}$ is the mass of the sample after passing through the machine.

The moisture content of the compressed WH samples by developed machine of about $83.2 \%$, w. b. are used in the experimental work as a compressed $\mathrm{WH}$ samples to study their drying behaviors.

\section{Solar collector and multi-tray tunnel drier:}

A schematic diagram of the experimental setup showing the locations of all measurement devices, dimensions, the side view and elevation of the collector and multi-tray drier and the name parts are shown in Fig 1. This dryer was manufactured and tested by Shoughy et al., (2013) for drying fish and used for drying WH to extend 
the operational use and consequently decreasing the operating cost per hour. The dimensions of solar air collector were $110 \mathrm{~cm}$ wide, $310 \mathrm{~cm}$ long and $15 \mathrm{~cm}$ height. A corrugated galvanized iron sheet painted black was used as an absorber plate for absorbing the solar radiation. It was oriented to the south under the collector angle of $30^{\circ}$ for maximum solar energy in Kafrelsheikh as recommended by Eltawil and Imara (2005). A clear plastic film was used as a transparent cover for the solar collector. Fiber glass wool blanket having a thickness of $2.5 \mathrm{~cm}$ was used as insulation material to prevent heat losses from the sides and bottom of the solar collector. Heated air in the solar collector was forced through the drying chamber by a radial fan ( $40 \mathrm{~W})$. The airflow rates were adjusted by using the fan regulator. The multi-tray solar tunnel drier, which made mainly of wood has $200 \times 400 \mathrm{~cm}^{2}$ base area and $260 \mathrm{~cm}$ height, is used for the drying experiments. The tunnel was oriented in an east-west direction to make the incident solar radiation more efficient on the solar drier. The dryer tunnel was covered with clear plastic film material. Sex drying trays, having dimensions of $150 \mathrm{~cm} \times 180 \mathrm{~cm}$, were placed in the drying chamber. Three of them were placed in the front side of the tunnel and the other three trays were placed in the rear side. Solar radiation also passes through the transparent cover and heats the products in the drier. These trays were used to accommodate complete and compressed WH to be dried. Solar radiation also passes through the transparent cover and heats the products in the drier. Consequently, the WH is dried by a combination of convective heating of the solar heated air by collector and the direct radiation through the plastic cover of the drier. This enhances the drying rate and the temperature in the drier. More details about the collector and drier specifications and performance are found in

Shoughy et al., (2013).

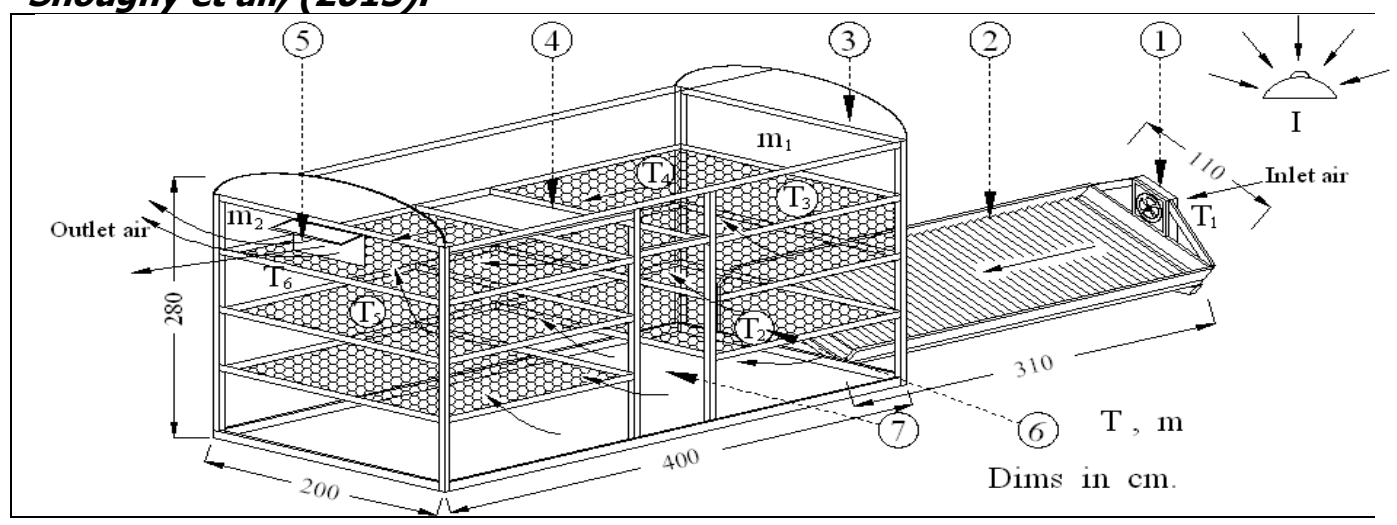




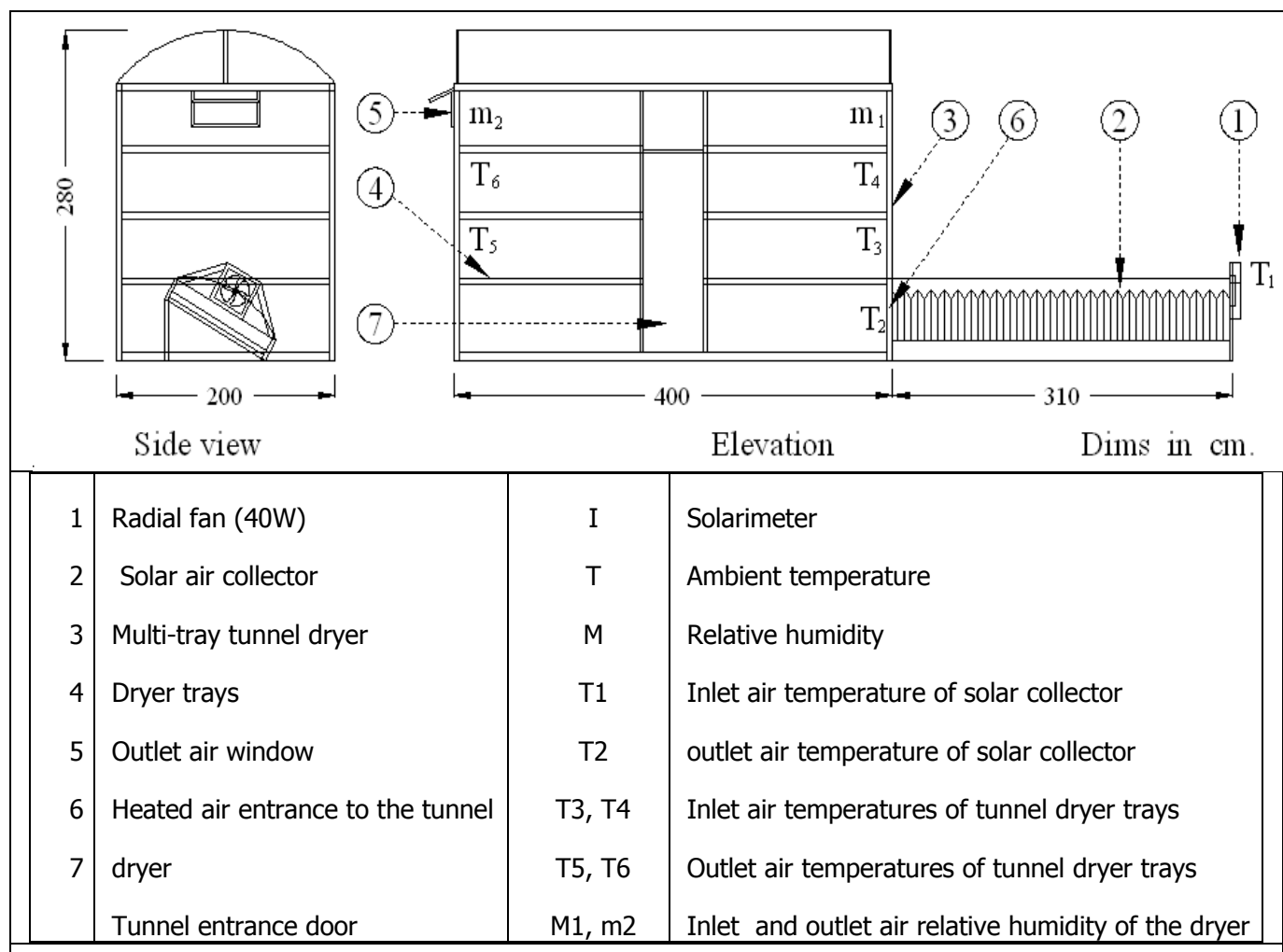

Fig. 1. A schematic diagram of the setup and locations of measurement devices (top), side view and elevation (bottom) and the name parts of the multi-tray solar dryer.

Source: (Shoughy et al., 2013)

\section{Procedures and measurements:}

A Solarimeter with a recorder model ( $Y$ 3057-11) was employed to measure the solar radiation flux incident on a horizontal surface outside the solar collector as shown in Fig. 1. The dry temperatures of the ambient and inside of the collector and multi-tray tunnel drier were measured hourly with the temperature thermocouples probes connected to an Interface Analog digital Converter, model (LE 1000). The relative humidity outside and inside the collector and drier and the airflow rate of drying air at the outlet of the collector was measured by a Thermal Anemometer, model (Sato SK-73D). The WH was spread on a wire mesh net in a single layer thickness which was covered all trays for each form of the drier portion. The test was conducted with $15 \mathrm{~kg}$ freshly complete $\mathrm{WH}$ and $20 \mathrm{~kg}$ of compressed $\mathrm{WH}$ in each tray to study the drier performance. It could easily accommodated 90 and $120 \mathrm{~kg}$ of complete and compressed WH in 6 trays. For all drying tests, the drier was manually loaded with the products to be dried and the fan was started at 08:00 am at 0.25m/s as a recommended airflow rate of thin layer for solar tunnel drying (Basunia et al., 2011) and continued till 06:00pm. After 06:00 pm, the fan stopped and the airflow gate in the solar drier was closed by polyethylene sheet in order to induce diffusion of moisture within the drying samples. This was open in the next morning and the fan 
started again and the process repeated until final moistures content was reached. To determine the mass loss of the WH during experimental work, the liable samples were taken and massed each one hour with an electric balance having an accuracy of $0.001 \mathrm{~g}$. Moisture content was expressed as a dry basis otherwise reported. It was considered that no drying would take place over night, except the internal moisture migration within the products. Also, to compare between the samples dried in multitray solar drier with that of open sun drying, control samples, $1 \mathrm{~kg}$ of each $\mathrm{WH}$ samples were distributed on a tray at the same loading density near the solar drier. Both the solar and sun drying samples were dried simultaneously under the same weather conditions.

\section{Moisture content and drying rate determination:}

The amount of moisture in a product is designated on the dry basis (Casas et al., 2012):

$$
M C, d b, \%=\frac{m_{w}}{m_{d}} \times 100 \%
$$

Where: $M C$ is moisture content at any time, $m_{w}$ is the wet mass of the sample and $\mathrm{md}$ is the dry

$$
\text { mass of the sample. }
$$

Drying rate after the complete drying periods was calculated as the following:

$$
\text { Drying rate, } \frac{(\mathrm{kg} \text { water } \mid \mathrm{kg} \text { dry matter })}{\mathrm{h}}=\frac{M C_{i}-M C_{f}}{\text { time }}
$$

Where: $M C_{i}$ is the initial moisture content and $M C_{f}$ is the final moisture content.

\section{Drying condition and thin layer drying equation fitting:}

For all experimental conditions, the value of moisture ratio expressing dimensionless moisture content obtained as expressed by Olawale and Omole (2012). The nonlinear regression analysis in the present study was performed using the software MATLAB 7.0. The effect of heat transfer is neglected as a simplifying assumption. The data between drying rate versus drying time was plotted. All values were determine as mean values of three replicates and expressed as $\mathrm{kg}$ water $/ \mathrm{kg}$ dry matter. The moisture ratio (MR) during drying experiments was calculated using the following equations:

$$
M R=\frac{M-M_{e}}{M_{i}-M_{e}}
$$

Where: $M, M_{i}$ and $M_{e}$ are moisture content at any time, initial moisture content, moisture content in equilibrium with the drying air.

However, $M R$ is the simplified to $M / M_{i}$ instead of Eq. (4) because the values of $M_{e}$ may be relatively small compared to $M$ and $M_{i}$, the long drying time as well as the continuous fluctuation of the relative humidity of the drying air during their drying processes. To determine the drying characteristics of the WHs, the experimental data 
were fitted into four different models as presented in Table 1. These models described the relationship between moisture loss and drying time with various coefficients attached to each model. The coefficient of determination $\left(R^{2}\right)$ was one of the important criteria to select the best equation in the solar drying curves of the drying agricultural products. In addition to $\mathrm{R}^{2}$, the various statistical parameters such as: reduced Chi-square $\left(x^{2}\right)$, mean bias error $(\mathrm{MBE})$ and the root mean square error (RMSE) were used to determine the quality of the fit (Fadhel1 et al., (2011) and Ajala et al., 2012). Reduced mean square of the deviation $\left(x^{2}\right)$ is used to determine the goodness of the fit. The lower the values of the $x^{2}$, the better the goodness of the fit. The RMSE gives the deviation between the predicted and experimental values and it is required to reach zero.

Table 1: Mathematical thin layer drying models given by various authors for the solar drying curves

\begin{tabular}{|c|c|c|c|}
\hline Number & Model name & Model equation $^{1}$ & \multicolumn{1}{|c|}{ References } \\
\hline 1 & Newton & MR $=\exp (-\mathrm{kt})$ & Ajala et al.,(2012) \\
2 & Page's & MR $=\exp \left(-\mathrm{kt}^{\mathrm{n}}\right)$ & Ajala et al.,(2012) \\
3 & Henderson and Pabis & $\mathrm{MR}=\mathrm{a} \exp (-\mathrm{kt})$ & Guan et al., (2013) \\
4 & Logarithmic & MR= a exp (-kt) $+\mathrm{c}$ & Kamalakar et al., \\
& & & $(2013)$ \\
\hline
\end{tabular}

1 MR: moisture ratio, decimal, $t=$ drying time, $s, k=$ drying constant, $s^{-1}$ and $a, n$, c: empirical coefficients in drying models

These parameters can be calculated as the following equations (Radhika et al., 2011):

$$
\begin{aligned}
& R^{2} \\
& =\frac{\sum_{i=1}^{n}\left(\mathrm{MR}_{\mathrm{i}} \cdot \mathrm{MR}_{\mathrm{pre}, \mathrm{i}}\right) \cdot \sum_{i=1}^{n}\left(\mathrm{MR}_{\mathrm{i}} \cdot \mathrm{MR}_{\mathrm{exp}, \mathrm{i}}\right)}{\sqrt{\left[\left(\mathrm{MR}_{\mathrm{i}} \cdot \mathrm{MR}_{\mathrm{pre}, \mathrm{i}}\right)^{2}\right] \cdot\left[\left(\mathrm{MR}_{\mathrm{i}} \cdot \mathrm{MR}_{\mathrm{exp}, \mathrm{i}}\right)^{2}\right]}} . \\
& X^{2}= \\
& \frac{\sum_{\mathrm{i}=0}^{\mathrm{n}}\left(\mathrm{MR}_{\mathrm{exp}, \mathrm{i}}-\mathrm{MR}_{\mathrm{pre}, \mathrm{i}}\right)^{2}}{\mathrm{~N}-\mathrm{n}} . \\
& M B E=\frac{1}{N} \sum_{\mathrm{i}=0}^{\mathrm{n}}\left(\mathrm{MR}_{\mathrm{exp}, \mathrm{i}}-\mathrm{MR}_{\mathrm{pre}, \mathrm{i}}\right) \\
& \mathrm{SMRE}=\sqrt{\frac{\sum_{\mathrm{i}=0}^{\mathrm{n}}\left(\mathrm{MR}_{\text {exp }, \mathrm{i}}-\mathrm{MR}_{\mathrm{pre}, \mathrm{i}}\right)^{2}}{\mathrm{~N}}}
\end{aligned}
$$


The best model describing the drying behavior of WH was chosen as the one with the highest coefficient of determination and the least values of reduced Chisquare error, mean bias error and root mean square error.

\section{Effective moisture diffusivity:}

The effective diffusivity of the samples is estimated by using the simplified mathematical Fick's second diffusion model in infinite-plate geometry, with the assumptions of moisture migration being by diffusion, negligible shrinkage and temperature. The diffusion coefficient of the complete and compressed WH samples $\left(D_{\text {eff }}\right)$ was typically calculated by plotting experimental drying data in terms of $\ln (M R)$ in Equ. 9 versus drying time give a straight line with a slope. The equation is expressed as the following (Ajala et al., 2012):

$$
\operatorname{Ln} M R=\operatorname{Ln} \frac{8}{\pi^{2}} \exp \frac{-\pi^{2} D_{\text {eff }} t}{4 L^{2}} \ldots
$$

Where: $M R$ is the dimensionless moisture ratio, $D_{\text {eff }}$ is the effective moisture diffusivity in $\mathrm{m}^{2} / \mathrm{s}$,

$t$ is the time of drying in seconds and $L$ is half of the sample thickness in meter.

The effective diffusivity can be calculated using method of slopes as the following:

$$
\text { Slope } K=\frac{D_{e f f} \pi^{2}}{4 L^{2}}
$$

The model that best described the drying behavior of the samples was used to evaluate the moisture diffusivity of the samples.

\section{Statistical analyses:}

The nonlinear regression analysis in the present study was performed using the software MATLAB 7.0. Mean values and their standard deviation were calculated and tested on their significant differences and the linear equations were fitted to the data using the LINEST function in Microsoft Excel.

\section{RESULSTS AND DISCUSSION}

\section{Solar drying conditions of the complete and compressed WH:}

The variations of the ambient, collector, and drier air temperatures, relative humilities and solar radiation with accumulated drying time (10hs a day) during drying experiments in two days (11-12June, 2013) have been shown in Fig. 2. The drying chamber reaches the highest temperatures, this could be due to direct and indirect heating. The direct heating is caused by the solar radiation that shines directly inside the drying chamber and on the WH. The indirect heating is caused by the collector's heated air, which is blown into the drying chamber. During the drying experiments, the average temperature and relative humidity of ambient air was $30.3^{\circ} \mathrm{C}$ and $48.5 \%$, 
average air temperature and relative humidity of the dryer was $51.5^{\circ} \mathrm{C}$ and $35.4 \%$ and solar radiation of about $520 \mathrm{~W} / \mathrm{m}^{2}$ respectively. The drying temperature and relative humidity under solar drying varied continuously with increasing drying time. The suggested collector and multi-tray solar drier considerably increased the drying air temperature by about $21.2^{\circ} \mathrm{C}$ and reduced relative humidity by about $13.1 \%$. This result also indicated that the average temperature in the collector part was slightly lower than the average temperature in the drier part because of the presence fan at the air entrance side of the collector and also due to the direct radiation through the plastic cover of the drier. Air humidity affected drying because the higher the drying air humidity, the slower drying proceeded and therefore a longer time was required for drying. It can be seen that the potentiality of the drying air was not fully utilized as the humidity of drying air leaving the drier in average of $35.4 \%$, was much less than the ambient air humidity $48.5 \%$. This explicitly indicates that the drying rate in multitray solar drying is higher than that in open sun drying. The same observation was reported from earlier research by Othman et al., (2013) in different weather conditions.

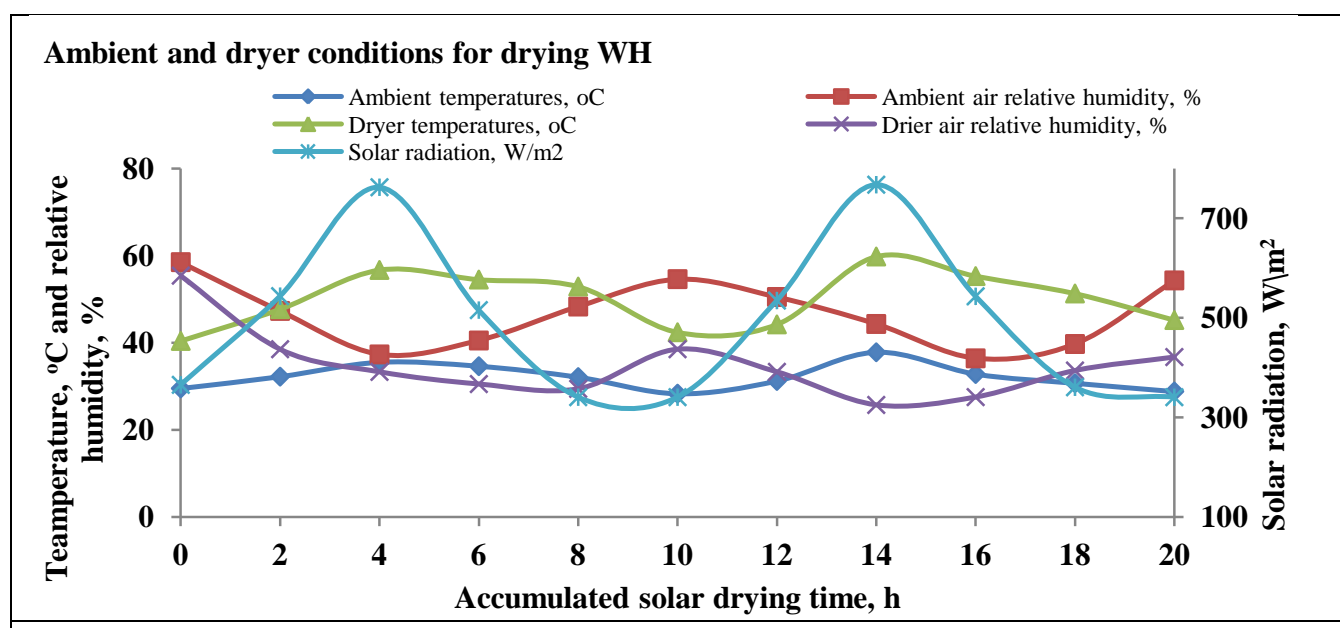

Fig. 2. Variations of ambient and dryer temperatures and solar radiations during accumulated drying time (10 hours a day at 11-12, June, 2013) in drying WH.

\section{Moisture content and drying rates of the complete and compressed WH:}

The drying behavior of the $\mathrm{WH}$ is shown in Figure 3. The reduction rate of dried WH moisture content was depended upon the solar air drying temperature and decreased with the increase of drying time. Drying complete WH from 10.8 to $0.104 \mathrm{~kg}$ water/kg dry matter in the multi-tray solar drier required 20hrs, while drying compressed WH from 4.9 to $0.85 \mathrm{~kg}$ water $/ \mathrm{kg}$ dry matter required only $15 \mathrm{hrs}$. While, the sample dried in open sun drying to $1.15 \pm 0.2 \mathrm{~kg}$ water $/ \mathrm{kg}$ dry matter in 40 and 30 hrs (10hours a day) for complete and compressed $\mathrm{WH}$, respectively. The highest final moisture content of about $9.8 \%$, $d b$, was obtained of complete WH samples 
probably due to the high initial moisture content before drying and the waxy surface of the plant outer cells. However, the lower final moisture contents attained in compressed $\mathrm{WH}$ of $6.5 \%$, db, by solar drying due probably to its passes in the machine that compressed out some of the initial water prior to drying. The significance of drying is seen in the role it plays in expelling residual intracellular fluid from the sample which could not have been expelled through compressing. This was made possible by the breakage of water hyacinth structure, including the cuticle, hence exposing the internal parts of the sample for direct drying.

Effect of accumulated solar drying time on the drying rates of complete and compressed WH was also studied and the results are shown in Fig. 4. The result was expressed that the complete $\mathrm{WH}$ had a faster drying rate than compressed samples due to the higher initial moisture content, resulting in the difference of moisture removal. While, the drying rate of complete $\mathrm{WH}$ and compressed $\mathrm{WH}$ was increased by 1.5 and 2 times, respectively by using multi-tray solar drier as compared to sun dried samples. It was also found that the drying rate was increased during the first 5hrs and then decreased continuously with decreasing moisture content and increasing drying time. The drying time of compressed WH was shortened by $25 \%$ compared with the complete $\mathrm{WH}$ during drying process due to increased surface area exposed for a given volume of the product. The longer drying time of complete $\mathrm{WH}$ could be attributed to the waxy surface on the plant cuticle. After the surface is dried the wax is broken due to high temperature inside the dryer, and some of the moisture from inside can be released. While, the increasing drying rate of compressed $\mathrm{WH}$ in the first drying period with increasing drying time may be due to release the waxy surface from the cells damaged during compressing process might also result in the opening of the porous spaces that have an effect on the process of drying. This result applied with the result obtained by Casas et al., (2012). Also, solar drying accelerates the drying which leads to a considerable reduction in drying time, while sun drying requires 30-40hrs for drying compressed and complete $\mathrm{WH}$, respectively. A $50 \%$ saving in drying time were obtained for solar drying WH compared to open sun drying method. This is due to the fact that the product in the drier received energy both from the collector and from incident radiation, while the sun dried samples received energy only from incident radiation and lost significant amount of energy to the environment. Since time was a major factor, materials which dried in less time consumed less energy, hence it was deduced that compressed WH dried faster than complete $\mathrm{WH}$ samples and consequently consumed less energy. 


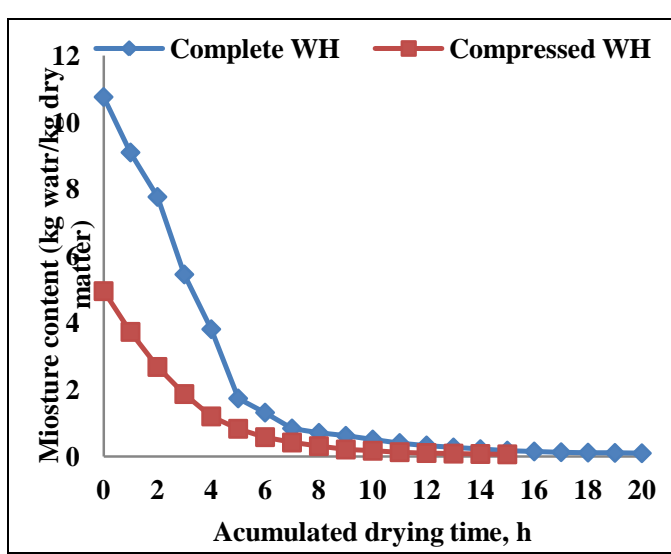

Fig. 3. Effect of accumulated solar drying time on the moisture content of WH.

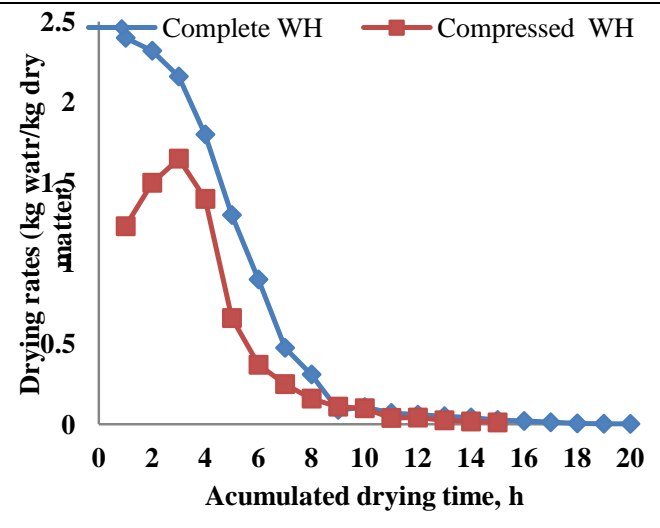

Fig. 4. Effect of accumulated solar drying time on the drying rates of $\mathrm{WH}$ (kg water/kg dry matter).

\section{Moisture ratios, drying coefficients and fitting of the drying curves:}

The moisture ratio is reduced exponentially with drying time which is typical of most fruits and vegetables and reduced faster in the beginning than that at the end of drying period. All the drying operations are seen to occur in the falling rate period as shown in Fig. 5. During the falling rate drying period, the drying rate decreases continuously with decreasing moisture content and increasing drying time which indicated that diffusion is the most likely physical mechanism governing moisture movement in WH. Similar results have been reported in the literature such as Casas et al., (2012) for WH. The drying data as the moisture ratio (MR) obtained experimentally versus drying time were fitted to the four drying models. Table 2 shows the comparison criteria used to evaluate goodness of fit, namely the coefficient of determination $\left(\mathrm{R}^{2}\right)$, reduced Chi-square $\left(\chi^{2}\right)$, mean bias error (MBE) and the root mean square error (RMSE) for WH dried by solar tunnel drying. The values of $R^{2}, x^{2}$, MBE, and RMSE for models range from 0.9655 to $0.9978,0.000201$ to $0.02383,6.54$ to $28.2 \%$ and 0.00014 to 0.09513 , respectively. All the four models gave an excellent fit to the experimental data with a value for $R^{2}$ of greater than 0.9655 . Of all the models tested, the logarithmic model offered the highest value for $\mathrm{R}^{2}$ followed by Page's model. While, the values of MBE for the logarithmic model were less than $10 \%$ in all cases, which in the acceptable range. Also, the values for RMSE and $x^{2}$ obtained from this model were less than those attained from other models. According to Table 2, logarithmic model showed good agreement with the experimental data and gave the best result for drying WH samples (highest $R^{2}$ and lowest $X^{2}$, MBE and RMSE). Hence, the logarithmic model may be assumed to represent the thin-layer behavior of complete and compressed $\mathrm{WH}$ by using solar tunnel during drying period under Kafrelsheikh weather conditions. Figs: 5-7 suggest the experimental and predicted 
moisture ratio obtained using the logarithmic model for drying WHs. There was a good conformity between experimental and predicted moisture ratios. This indicates the suitability of the logarithmic model in describing the drying behavior of complete and compressed $\mathrm{WH}$ in the multi-tray solar tunnel drying in the range of the tested drying conditions. These results were agreement with the results obtained by Fadhel1 et al., (2011) and Casas et al., (2012).

Table 2. Thin layer drying coefficients results for different models.

\begin{tabular}{|c|c|c|c|c|c|}
\hline Materials & Models & $\mathrm{R}^{2}$ & $x^{2}$ & $\mathrm{MBE}, \%$ & RMSE \\
\hline Complete WH & Newton & 0.9655 & 0.02383 & 28.2 & 0.08065 \\
\hline Compressed WH & & 0.9752 & 0.02155 & 25.6 & 0.09513 \\
\hline Complete WH & Page's & 0.9745 & 0.000237 & 15.3 & 0.00028 \\
\hline Compressed WH & & 0.9843 & 0.000231 & 12.3 & 0.00022 \\
\hline Complete WH & Henderson and & 0.9741 & 0.000901 & 22.5 & 0.002893 \\
\hline Compressed WH & Pabis & 0.9814 & 0.000710 & 21.4 & 0.002482 \\
\hline Complete WH & Logarithmic & 0.9965 & 0.000225 & 8.53 & 0.00014 \\
\hline Compressed WH & & 0.9961 & 0.000201 & 6.54 & 0.00019 \\
\hline
\end{tabular}

\section{Effective moisture diffusivity:}

The values of effective diffusivity for various drying samples are evaluated. The dried compressed WH samples offered the highest values of $D_{\text {eff }}$ more than the complete WH samples. Effective moisture diffusivity values of complete and compressed WH of about $6.65 \times 10^{-8} \mathrm{~m}^{2} / \mathrm{s}$ and $8.16 \times 10^{-8} \mathrm{~m}^{2} / \mathrm{s}$, respectively. The values of moisture diffusivity in this study was in the suitable range of food products $\left(10^{-7}\right.$ to $\left.10^{-12}\right)$ as reported by Casas et al., (2012).

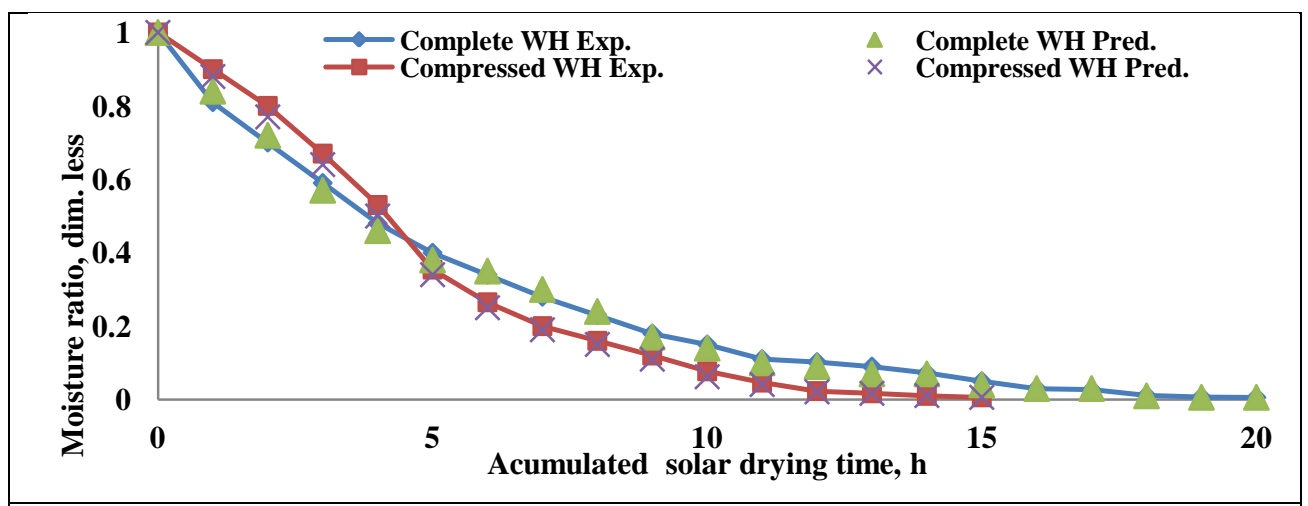

Fig. 5. Drying curves for the experimental and predicted data by Logarithmic model for complete and compressed WH samples. 


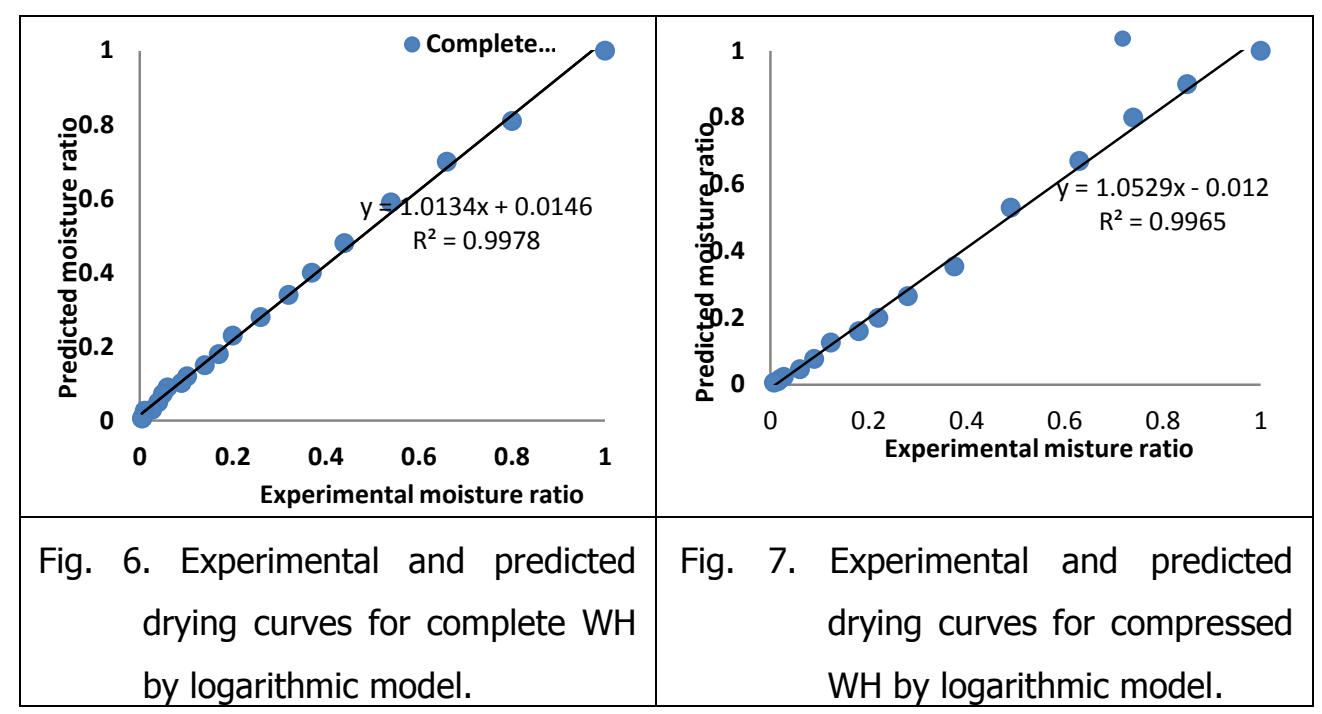

\section{CONCLUSION}

The suggested multi-tray solar tunnel dryer can be used for drying complete and compressed WH under the climatic conditions of Kafrelsheikh. The moisture content was reduced in two days. Shorter drying time and increased drying rates the beneficial effects of compressed process of WH. Drying rate for WH increased by $1.5-$ 2 times and $50 \%$ saving in drying time was recorded for solar drying relative to open sun drying. In order to explain the drying behavior of $\mathrm{WH}$, four different mathematical models were compared according to their coefficient of determination values, Chisquare $\left(\chi^{2}\right)$, mean bias error (MBE) and the root mean square error (RMSE) for solar tunnel drying. Drying curves of solar dried WH showed a falling rate-drying period only under the experimental conditions employed. Effective moisture diffusivity values of complete and compressed WH of about $6.65 \times 10^{-8} \mathrm{~m}^{2} / \mathrm{s}$ and $8.06 \times 10^{-8} \mathrm{~m}^{2} / \mathrm{s}$, respectively. The Logarithmic model considering the effective diffusion coefficient gave an excellent fit for the drying data of WH during experiment period. In the end, it is a good way to change waste products into useful things.

\section{REFERENCES}

1. Ajala, A. S., P.O. Ngoddy and J.O. Olajide. 2012. Statistical modeling and simulation of drying cassava chips in tunnel dryer. Intl. Journal of Emerging Trend in Engineering and Development, 2(7): 585-586.

2. AOAC. 2005. Official Methods of Analysis (18th Edn.) Association of Official Analytical Chemists. International, Maryland, USA.

3. Basunia, M. A., H. H. Al-Handali, M. I. Al-Balushi, M. S. Rahman and O. Mahgoub. 2011. Drying of Fish Sardines in Oman Using Solar Tunnel Dryers. J. of Agricultural Science and Technology, 1: 108-114.

4. Casas E. V., J. G. Raquid, K. F. Yaptenco and E. K. Peralta. 2012. Optimized drying parameters of water hyacinths (Eichhornia crassipes.L). Science Diliman, 24(2): 28-49. 
5. Eltawil, M. A. and Z. M. Imara. 2005. Utilization of photovoltaic array in a multitray fruits drying system for rural areas. The $13^{\text {th }}$ Annual Conference of the Misr Society of Agric. Eng., 22(4):820-845.

6. Fadhel1, M. I., R. A. Abdo, B. F. Yousif, A. Zaharim, and k. Sopian. 2011. Thinlayer drying characteristics of banana slices in a force convection. Indirect Solar Drying. Recent Researches in Energy \& Environment: 301-315.

7. Gokhan G., O. Necdet and G. Ali. 2009. Solar tunnel drying characteristics and mathematical modelling of tomato. J. of Thermal Sci. and Tech., 29(1): 15-23.

8. Goyal R. K., O. Muijeb and K.B. Vnod. 2008. Mathematical modeling of thin layer drying kinetics of apple in tunnel dryer. International Journal of Food Engineering 4(8): 8.

9. Guan, Z., X. Wang, L. Min and X. Jiang. 2013. Mathematical Modeling on Hot Air Drying of Thin Layer Fresh Tilapia Fillets. Pol. J. Food Nutrition, 63(1): 25-34.

10. Immaculate, J., P. Sinduja and P. Jamila. 2012. Biochemical and microbial qualities of Sardinella fimbriata sun dried in different methods. International Food Research J. 19(4): 1699-1703.

11. Innocent C.O., O. G. Lawrence and A. N. Gitau. 2008. Dewatering and Drying Characteristics of Water Hyacinth (Eichhornia Crassipes) Petiole. Part II. Drying characteristics" Agricultural Engineering International: the CIGR E j. Manuscript FP 07033. Vol. X.:1-11.

12. Kamalakar, D., L. Nageswara, K.S. Prasada and M. Venkateswara. 2013. Studies on drying characteristics of prawn and fish. J. of Chemical, Biological and Physical Sciences, 3(3): 1972-1982.

13. Olawale, A. S. and S. O. Omole. 2012. Thin layer drying models for sweet potato in tray dryer. Agric Eng Int: CIGR J., 14 (2): 131-137.

14. Othman A. M. Y, M. H. Ruslan and K. Sopian. 2013. Drying of Malaysia Capsicum annuum L. (Red Chili) Dried by Open and Solar Drying. International J. of Photo energy, Article ID 167895, 9 pages, http://dx.doi.org/10.1155/2013/16789.

15. Radhika, G.B., S. V. Satyanaray and B.V. Raju. 2011. Mathematical model on thin layer drying of finger millet (Eluesine coracana). Adv. J. Food Sci. Technol., 3(2): 127-131.

16. Shoughy, M. I, A. A. EL-Keway and S. K. Genidy. 2013. Development and evaluation of multi-tray solar drier for drying fish. The $3^{\text {rd }}$ International Conference of Agricultural and Bio-Engineering."Engineering Application for Sustainable Agriculture Development". 14 November, 2013, Giza, Egypt.

17. Xingxing, Z., Z. Xudong, S. Stefan, X. Jihuan and Y. Xiaotong. 2012. Review of R and $D$ progress and practical application of the solar photovoltaic/thermal (PV/T) technologies, Renewable and Sustainable Energy Reviews, 16: 599-617. 


\title{
خصائص التجفيف لياسنت الماء بإستخدام مجفف شمسي متعدد الصواني
}

\author{
محمد إسماعيل شوغي ،عادل فتحي عبده عبد ربه ،علي بدوي النجار \\ معرج بحوث الهندسة الزراعية - مركز البحوث الزراعية - الدقى - الجبيزة - مصر.
}

يعتبر ياسنت الماء (ورد النيل) من أهم الحشائش التي تسبب مشاكل في المجارى المائيــة فــى مصر و العالم. و المشكلة الكبرى تتمثل فى تكلفة التخلص منه من الترع و المصارف بغرض تطهيرها وكذلك تكلفة النقل الكبيرة لهذا المنتج كنبات أخضر من مكان تجميعه إلى مكان تصــنيعه بغـرض الاستفادة منه فى عديد من الإغراض كسماد عضوي اخضر أو مصنع ويستخدم كغــذاء للحيو انـات و الإنسان حيث تحتوى أور اقه علي نسبه عالية من البروتين وفيتامين أ. ويستخدم فى صناعة الورق و الثنط و الأثاث و الخشب وطوب البناء و استخر اج الايثانول و البيو ايثانول و الوقود الحيوي. و ارتفــاع نسبة الرطوبة به إلي بو\% تقريبا تسبب مشكلة كبيرة عند المقاومة الميكانيكية حيث تقـل الكفــاءة

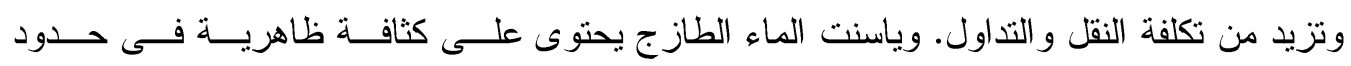

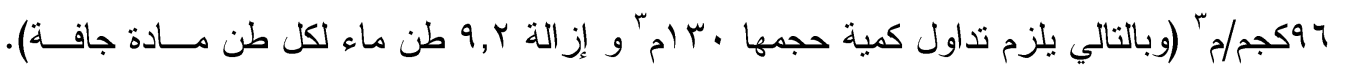
لذلك بلزم تقطيعه وكبسه وخفض حجمه ووزنه (زيادة كثافته) أو تجفيفه بغرض زيادة كفاءة عمليات النقل و التداول و الاستفادة منه كمنتج اقتصادي.

لذلك يهدف هذا البحث الي دراسة أداء مجفف شمسي متعدد الصواني يعمل بنظام الدفع الجبري للهو اء في تجفيف ياسنت الماء تحت الظروف المناخية بكفر الثيخ بالمقارنــة بــالتجفيف الثمســي. واختيار النموزج الرياضي المناسب لوصف خصائص التجفيف باستخدام الطاقة الثمسية. من أهم النتائج مايلي: والنيان ا. كان متوسط درجة الحر ارة للهو اء المحيط ودرجة الحرارة داخل المجفف و الرطوبــة النســبية

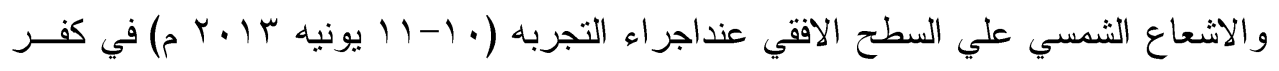

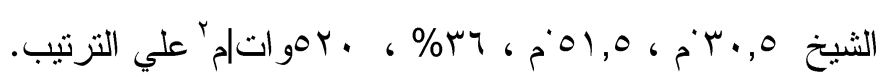

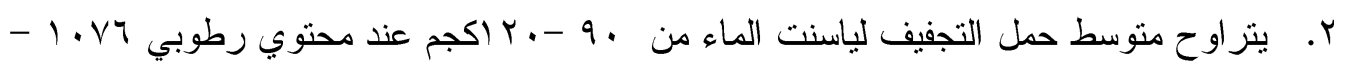

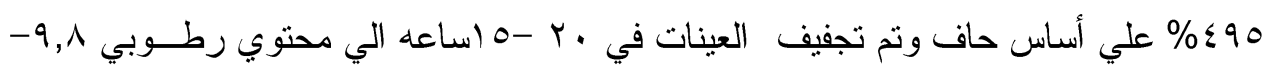

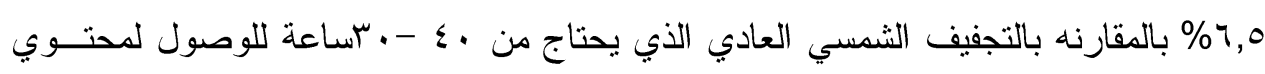
رطوبي حو الي 18.5\% عند تجفيف ياسنت الماء الطازج و المكبوس على التو الي. 
ب. استخدام المجفف المقترح أدي الي زيادة معدل التجفيف فى ياسنت الماء بحــو الي الضــف وبالتالي انحفض الزمن اللازم لتجفيف بمقدار 50\% بالمقارنه بالتجفيف الشمسى العادى. وكان الزمن اللازم للتجفيف في ياسنت الماء المكبوس أقل بمقدار هب \% عن زمن ياســت المــاء

$$
\text { الطازج. }
$$

ء. استخدام النموزج الرياضي اللوغارتمي يعتبر الامثل في تحليل النتائج حيث اعطي أعلي معامل تقدير وأقل خطأ معنوي عن باقي النمازج الاخري في وصف خصائص التجفيف لباسنت الماء الطازج و المكبوس.

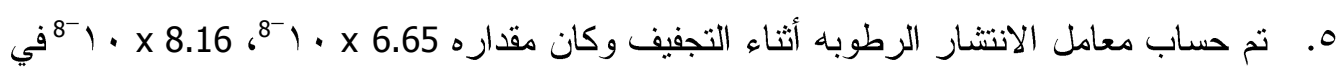
ورد النيل الطازج و المكبوس علي التو الي.

مما سبق يتضح أن هذا المجفف المقترح يمكن أن يستخدم في تجفيف ياسنت الماء الطازج و المكبوس في أماكن انتاجه والتي لا يوجد بها شبكة كهرباء حيث أن القدرة اللازمة لتنغيل مروحة التهوية للمجف منخفضه يمكن الحصول عليها مستقبلا من خلية شمسية صغيرة. و النموزج الرياضي المقترح يمكن أن يستخدم فى برنامج حاسب آلي للتنبؤ بظروف التجفيف وتصميم المجفات التي تستخدم على النطاق الاقتصادي. 